\title{
2021 Handbook of Florida Water Regulation: Safe Drinking Water Act $^{1}$
}

\author{
Michael T. Olexa, Tatiana Borisova, and Jana Caracciolo
}

\section{Preface}

This handbook is designed to provide an accurate, current, and authoritative summary of the principal federal and state (Florida) laws that directly or indirectly relate to agriculture. This handbook provides a basic overview of the many rights and responsibilities that farmers and farmland owners have under both federal and state laws as well as the appropriate contact information to obtain more detailed information. However, the reader should be aware that because the laws, administrative rulings, and court decisions on which this handbook is based are subject to constant revision, portions of this publication could become outdated at any time. Several details of cited laws are also left out due to space limitations. This handbook is provided as an educational text for those interested in water use and water resource issues in Florida.

This handbook is distributed with the understanding that the authors are not engaged in rendering legal or other professional advice, and the information contained herein should not be regarded as a substitute for professional advice. This handbook is not all inclusive in providing information to achieve compliance with the federal and state laws and regulations governing water protection. For these reasons, the use of these materials by any person constitutes an agreement to hold harmless the authors, the UF/IFAS Center for Agricultural and Natural Resource Law, and UF/IFAS Extension for any liability claims, damages, or expenses that may be incurred by any person as a result of reference to or reliance on the information contained in this handbook. Note: UF/IFAS is the acronym for University of Florida, Institute of Food and Agricultural Sciences.

\section{SDWA Overview}

The federal Safe Drinking Water Act (SDWA) was passed in 1974 and has been amended several times to expand both its breadth and the United States Environmental Protection Agency's (EPA) power to enforce it. SDWA's primary purpose of stopping contaminants from entering drinking water systems is accomplished by doing the following:

- Authorizing EPA to set national health-based water quality standards for tap water (note that SDWA does not apply to private wells that serve fewer than 25 people)

- Monitoring public water systems

- Guarding against groundwater contamination from injection wells

SDWA aims to eliminate the pollution in drinking water by protecting water quality from the source to the tap. Threats to drinking water, such as animal wastes, pesticides, and wrongfully disposed chemicals, could contaminate water at its source. SDWA provides operator training and funding for water system improvements to ensure that water

1. This document is FE587, one of a series of the Food and Resource Economics Department, UF/IFAS Extension. Original publication date October 1998. Revised June 2017 and April 2021. Visit the EDIS website at https://edis.ifas.ufl.edu for the currently supported version of this publication.

2. Michael T. Olexa, professor, Food and Resource Economics Department, and director, UF/IFAS Center for Agricultural and Natural Resource Law, and member of The Florida Bar; Tatiana Borisova, associate professor, Food and Resource Economics Department; and Jana Caracciolo, student, Levin College of Law; UF/IFAS Extension, Gainesville, FL 32611.

The Institute of Food and Agricultural Sciences (IFAS) is an Equal Opportunity Institution authorized to provide research, educational information and other services

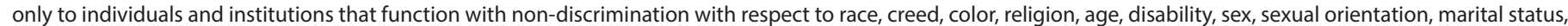

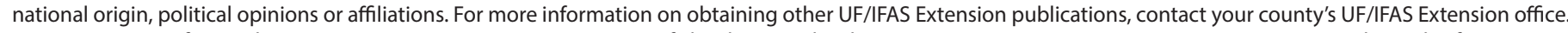
U.S. Department of Agriculture, UF/IFAS Extension Service, University of Florida, IFAS, Florida A \& M University Cooperative Extension Program, and Boards of County Commissioners Cooperating. Nick T. Place, dean for UF/IFAS Extension. 
containing any threats is properly treated or disinfected. For more information on understanding the SDWA see the EPA website: https://www.epa.gov/sdwa.

Among the areas of SDWA coverage, the regulation and permitting of injection wells probably has the most direct agricultural implications. Underground injection endangers drinking water sources if such injection introduces contaminants in underground water that may eventually affect drinking water quality. While the term "injection well" usually implies a very deep well, the definition of "injection" under SDWA may encompass several types of runoff, including irrigation return flow that enters the groundwater. Regulatory agencies therefore regulate the activity of the injection wells, not the wells themselves.

\section{Who enforces SDWA?}

In virtually all states, including Florida, EPA has given up enforcement of SDWA and now serves only to supervise the state programs approved to take its place. In Florida, the Department of Environmental Protection (FDEP) is the primary agency enforcing SDWA, with the Florida Department of Health also oversighting some programs in several counties. While the state has the primary role in enforcing SDWA, the 1986 amendments to SDWA gave EPA increased authority to step in and enforce SDWA if the state takes no action within 30 days of receiving notice from EPA that the water quality standards of SDWA have been violated. The states must also adopt all new and revised national regulations in order to continue to retain primary enforcement powers.

\section{What does SDWA prohibit?}

Through requirements for injections practices, SDWA ensures that injection wells do not endanger any future or current underground sources of drinking water. Facilities that conduct underground injection are subject to regulation. Regulations under SDWA create categories of injection wells with different requirements for each. Some injection wells (e.g., hazardous waste wells) are prohibited, while others are subject to various permitting, recordkeeping, reporting, and testing requirements. Wells are evaluated in classes, from Class I to Class VI. For example, wells that are used to inject non-hazardous fluids underground (such as agricultural drainage wells, aquifer storage and recovery wells, and septic system leach fields) are included into Class V. For such wells, owner or operator is required to submit inventory information to the Florida Department of Environmental Protection, operate the well so that it does not endanger the underground source of drinking water, and properly close the well when it is no longer in operation. The permitting authority to submit inventory information differs depending on the Class. For a list of Florida's permitting authority in each Class, see https:// www.epa.gov/uic/underground-injection-control-eparegion-4-al-fl-ga-ky-ms-nc-sc-and-tn\#primacy.

For information on well classification and requirements to various well classes, see http://water.epa.gov/type/groundwater/uic/wells.cfm.

\section{What are the penalties under SDWA?}

Violations of underground injection well regulations can result in administrative penalties of up to $\$ 125,000$. Civil penalties of up to $\$ 25,000$ per day are also available, along with criminal penalties of up to three years' imprisonment, in lieu of or in addition to civil penalties, for willful violations. In all cases, EPA is required to take action if the states fail to do so.

\section{Sources}

42 United States Code, Sections 300f to 300j-26

Additional resources from EPA can be found at https:// www.epa.gov/sdwa and https://www.epa.gov/uic/ general-information-about-injection-wells

For further information about SDWA, see http://water. epa.gov/lawsregs/rulesregs/sdwa/index.cfm. For Florida Drinking Water Program, see http://www.dep.state.fl.us/ water/drinkingwater/index.htm.

\section{Acknowledgments}

The authors are indebted to the personnel of both state and federal agencies who provided their time and advice in the preparation of this handbook. We acknowledge Carol Fountain and Susan Gildersleeve at the University of Florida for their assistance in editing this handbook. We also acknowledge funding received for updating this publication from the James S. and Dorothy F. Wershow UF/ IFAS Center for Agricultural and Natural Resource Law Endowment. 